NJE Vol. 36: 139-145, 2020

Nigerian Journal of Entomology

Published by the Entomological Soc. of Nig.

www.esnjournal.com.ng

DOI.10.36108/NJE/0202/63.01.61

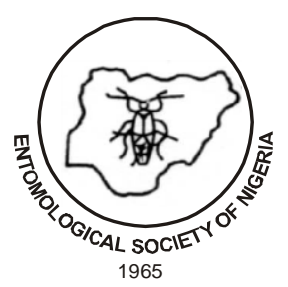

\title{
Seasonal Differences in the Abundance of Tsetse Flies (Glossina Species) in Pantaki, Kaduna State
}

\author{
Umar, Y.A., ${ }^{1}$ Denwe, S.D., ${ }^{1 *}$ Anchau, R.G., ${ }^{2}$ Attahir, A., ${ }^{2}$ Kugu, B.A., ${ }^{2}$ Jabiru, G., ${ }^{2}$ \\ Benjamin, J.E., ${ }^{2}$ Abdurrahim, S. ${ }^{2}$ Hafsat, M. ${ }^{3}$ Musa, U.B. ${ }^{2}$ \\ Hadiza, M.K. ${ }^{2}$ and Saminu, A. ${ }^{2}$ \\ ${ }^{I}$ Department of Biological Science, Faculty of Sciences, Nigerian Defence Academy, Kaduna. \\ ${ }^{2}$ Nigerian Institute for Trypanosomiasis Research (NITR), Vector and Parasitological Studies \\ Department, P.M.B 2077, Kaduna State, Nigeria. \\ ${ }^{3}$ Onchocerciasis Dept. NITR \\ *Deceased
}

\begin{abstract}
Seasonal-differences in the abundance of tsetse flies in Pantaki was investigated between July and August, 2016 and January and February, 2017 in Kagarko. Standard bioconical trapping method was used to collect the insects. A total of 208 tsetse flies were caught of which 139 (66.8\%) were Glossina palpalis palpalis while 69 (33.2\%) were Glossina tachinoides revealing an overall apparent density of 3.7T/T/D. The results indicate a significant difference $(\mathrm{p}<0.05)$ in abundance of tsetse flies in the wet compared to the dry seasons. Also, both species were relatively more abundant during wet (G. palpalis palpalis $75.5 \%$, G. tachinoides $84.1 \%$ ) than dry (G. palpalis palpalis $24 \%$, G. tachinoides $15.9 \%$ ) seasons. The differences in abundance observed could be due to the favourable climatic condition. This call for deployment of tsetse fly control measures (during the wet season) in the area.
\end{abstract}

Keywords: G. palpalis palpalis, G. tachinoides, Season, Biconical Traps, Trypanosomiasis.

\section{INTRODUCTION}

Tsetse flies (Glossina spp.) are the primary vector of animal and human trypanosomiasis in tropical Africa; and are a continuing threat to public health, livestock production and agricultural development in which tsetse fly infestation constitute a major source of

*Correspondence email:

rukayyagarbaanchau@gmail.com economic loss (Desta et al., 2013). Eleven of the twenty-three known species of tsetse flies are found in Nigeria (Solano et al., 2010) infesting approximately $74 \%\left(686.488 \mathrm{~km}^{2}\right)$ of the country's landmass from Latitude $4^{0} \mathrm{~N}$ to Latitude $12^{0} \mathrm{~N}$ covering all the agroecological zones of the country (Jawonisi, 1988). Transmission of trypanosomes occurs largely among rural populations where activities such as agriculture and fishing 
expose people to the bite of tsetse fly (Muturi et. al., 2011; Okoh et al., 2012).

Trypanosomiasis is a major constraint for ruminant production in Africa, Asia and South America (Gutierrez et al., 2006; Taylor et al., 2008; Fernandez et al., 2009). Outbreak of the disease has been reported in some Northern and Southern parts of Kaduna State (Maikaje et al., 1991; Ahmed, 2007; Fajinmi et al., 2007; Okoh et al.,2012) resulting in constraint to livestock production. Although, studies have been carried out in many areas especially in the North and Central part of Nigeria (Onyiah et al., 1983; Isaac et al., 2016), adequate information on the true prevalence of the disease and density of fly population in these areas is still scanty to enable proper disease surveillance. These among other factors have prevented effective control of the disease (Kalu et al., 2001; Samdi et al., 2008; 2010; 2011). Although, there are reports of African Animal Trypanosomiasis prevalence however, those on tsetse infestation are old. This study assesses current infestation levels of
Glossina species in order to consolidate Tsetse and Trypanosomiasis control programmes in the area.

\section{MATERIALS AND METHODS:}

\section{Study Area}

Kagarko Local Government Area is geographically within Latitude $9^{0} 30^{\prime} \mathrm{N}$ and Longitude $7^{0} 43^{\prime} \mathrm{E}$ covering an area of 1,864 $\mathrm{km}^{2}$ with a human a population of 240,943 (NPC, 2006). It is located in the Northern Guinea Savannah characterized by woodland vegetation. The area has distinct wet and dry seasons from May to October and November to April, respectively. The mean annual rainfall is reported to be $1536 \mathrm{~mm}$ with an average of $28.6{ }^{\circ} \mathrm{C} \mid 83.5{ }^{\circ} \mathrm{F}$, April is the warmest month at $23.3{ }^{\circ} \mathrm{C} \mid 73.9{ }^{\circ} \mathrm{F}$ on average, August is the coldest month of the year (climate-data.org). Human activities in the area include: herding of cattle and crop farming with breeding of sheep, goat and chicken.



Map of Kagarko with sampling sites in the Pantaki Area 


\section{Tsetse Survey}

Tsetse flies were trapped for a period of two months during dry and rainy season using biconical traps (Okoh et al., 2012). Trapping of flies was carried out between the months of July and August, 2016 and January to February, 2017 for the rainy and dry seasons, respectively. For each month, seven traps were deployed and set at intervals of $100 \mathrm{~m}$ in suitable tsetse habitats. The temperature and relative humidity of each trapping point was recorded using a whirling hygrometer (Dede et al., 2005). Flies caught were harvested, counted, sexed and identified to specie level according to the markings on the abdomen, hind leg and colour of the thecal bulb of the proboscis (Davies, 1977). For Glossina palpalis species, the thecal bulb is dark brown, all tarsal segments of the hind leg are black and the first segment of the abdomen is square shaped while in Glossina tachinoides first segment of the abdomen is triangular.

\section{Apparent Density Determination}

The apparent density of fly was determined by dividing the total number of flies caught by the product obtained from the multiplication of the number of traps used by the trapping days. (Okoh et al., 2012).

Seasonal trapping rate of tsetse flies was calculated as the number of tsetse flies caught per season divided by the product of the number of traps deployed and the number of days multiplied by100 (Molaleane et al., 2011).

Seasonal trapping $(\%)=$ $\frac{\text { No. of flies caught per season }}{\text { Number of traps } X \text { number of days }} \times 100$

The data was calculated using analysis of variance (ANOVA).

\section{RESULTS}

\section{Distribution of Tsetse Flies in Pantaki}

Two hundred and eight (208) tsetse flies were collected during the period of study. Of these, One hundred and thirty nine (66.8\%) were morphologically identified as Glossina palpalis while the remaining sixty nine (33.2\%) were Glossina tachinoides. Student t-test analysis shows a significant $(\mathrm{P}<0.001)$ difference in the distribution of the two species in Pantaki area during the study period (Table 1).

\section{Seasonal Abundance of Tsetse Flies}

A total of one hundred and sixty three (163) glossina species were caught during the rainy months while forty five (45) tsetse flies were caught in the dry season months. These correspond to $78.4 \%$ and $21.6 \%$ of the total tsetse flies caught for wet and dry season months respectively, and also $66.8 \% G$. palpalis and $33.2 \%$ G. tachinoides. The seasonal trapping rates for the wet and dry seasons were 11.6 and 3.2 tsetse flies/trap/ day respectively. Data analysis shows a significant $(\mathrm{P}<0.001)$ variation in tsetse fly abundance between the 2 seasons (Table 2).

\section{Relative Seasonal Abundance of Glossina species}

The relative seasonal abundance of the two Glossina species identified in Pantaki is presented in Table 3. Both G. palpalis and G. tachinoides were relatively more abundant during wet season (G. palpalis: 75.5\%; G. tachinoides: $84.1 \%$; than during the dry season (G. palpalis: Dry 24.5\%; G. tachinoides: Dry 15.9\%). 
Table 1: Diversity of Tsetse Flies Species caught in the Pantaki Area of Kagarko

\begin{tabular}{llll}
\hline Tsetse species & No. collected & $\begin{array}{l}\text { Relative } \\
\text { proportion (\%) }\end{array}$ & $\boldsymbol{p}$ value \\
\hline G. palpalis & 139 & 66.8 & 0.001 \\
$\begin{array}{l}\text { G. tachinoides } \\
\text { Total }\end{array}$ & 69 & 33.2 & \\
\hline
\end{tabular}

Table 2: Seasonal variation of Tsetse Flies

\begin{tabular}{llclll}
\hline Seasons & $\begin{array}{l}\text { No. } \\
\text { collected }\end{array}$ & Trapping & rate & $\begin{array}{l}\text { Relative } \\
\text { proportion } \\
(\%)\end{array}$ & $\begin{array}{l}\boldsymbol{p} \text { value } \\
\left(\chi^{2}\right)\end{array}$ \\
\hline Wet & 163 & 11.6 & 78.4 & \\
Dry & 45 & 3.2 & 21.6 & $<0.001$ \\
Total & 208 & 3.7 & 100.0 & \\
\hline
\end{tabular}

F/T/D: Flies per trap per day.

Table 3: Relative Seasonal Abundance of Glossina species

\begin{tabular}{llllll}
\hline Species of flies & Seasons & & \multicolumn{2}{l}{$\begin{array}{l}\text { Relative seasonal } \\
\text { proportion (\%) }\end{array}$} & $\begin{array}{l}\text { Total and Relative } \\
\text { proportion (\%) }\end{array}$ \\
\hline & Dry & Wet & Dry & Wet & \\
$\begin{array}{l}\text { G.palpalis } \\
\text { G.tachinoides }\end{array}$ & 34 & 105 & 24.5 & 75.5 & $139(66.8)$ \\
Total & 11 & 58 & 15.9 & 84.1 & $69(33.2)$ \\
\hline
\end{tabular}

\section{Relative Abundance of Tsetse Flies in relation to temperature and relative humidity}

The mean seasonal temperature values recorded were $28.0^{\circ} \mathrm{C}$ (dry season) and $25.8^{\circ} \mathrm{C}$ (rainy season), with mean seasonal relative humidity values of $33.5 \%$ (dry season) and $59.8 \%$ (rainy season) respecttively. There was a significant variation $(p \leq 0.05)$ in the mean relative humidity over the two seasons.

Scatter plots of the number of tsetse flies caught per day and the daily variation in temperature and relative humidity indicated a positive relationship between relative humidity and the number of tsetse flies abundance. A significantly $(p \leq 0.05)$ strong positive correlation was also found between relative humidity. However, scatter plot of temperature and number of trapped tsetse flies showed that temperature inversely varies with tsetse fly abundance. Furthermore, a significantly $(p \leq 0.05)$ negative correlation was found between temperature and abundance of the flies. 


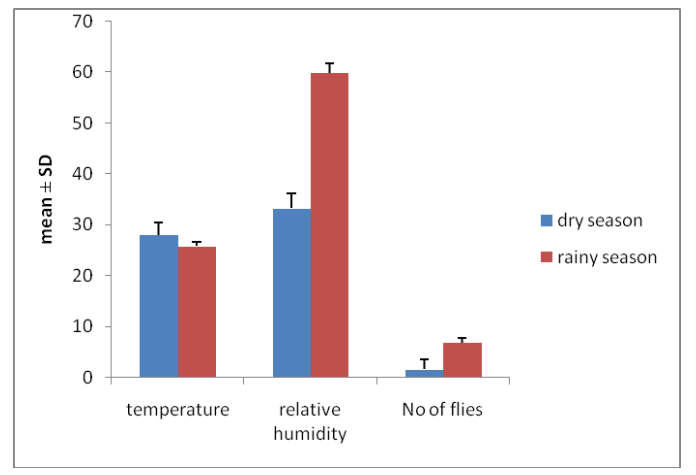

The Temperature and Relative Humidity of Tsetse Flies at Pantaki in dry and rainy season

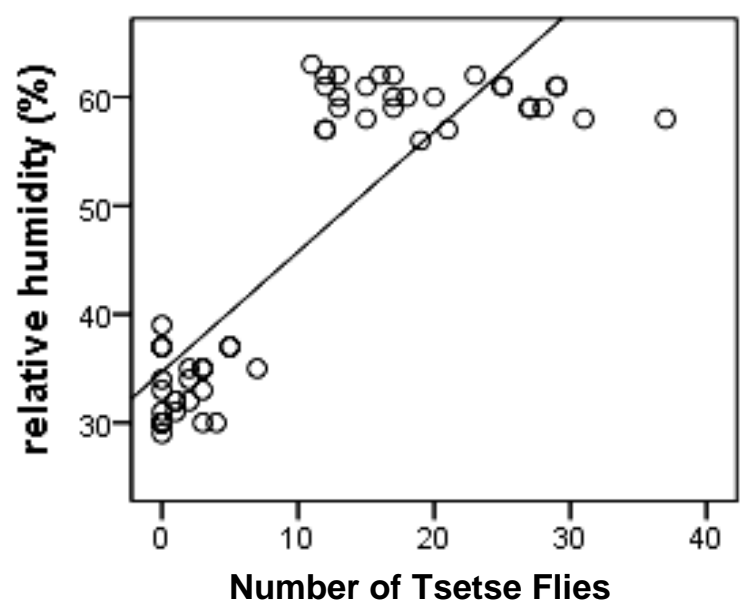

A scatter plot of the relative humidity and number of tsetse flies caught between July and August, 2016 and January and

February, 2017

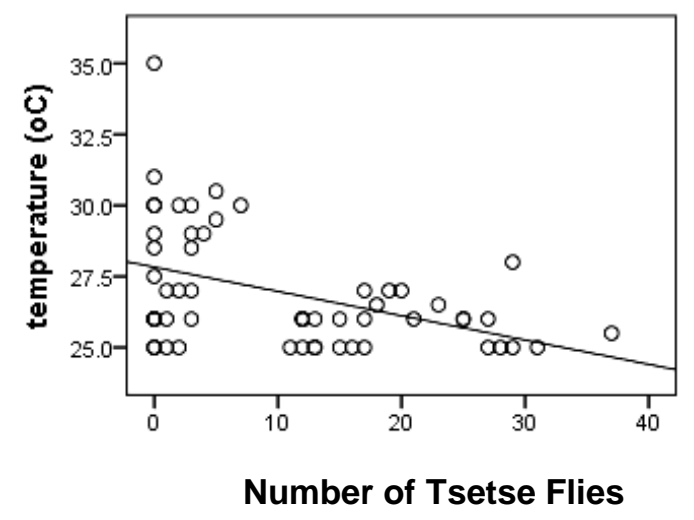

A scatter plot of the temperature and number of tsetse flies caught during the sampling period

\section{DISCUSSION}

Glossina tachinoides and G. p. palpalis, the two species of tsetse fly found in Pantaki have earlier been reported by Okoh et al. (2012) in Kamuku Park of Birnin Gwari; Ahmad (2005; 2007) in Kaura Local Government Area of Kaduna State; and Kalu (1991) in Barkin-Ladi Local Government Area of Jos Plateau. The two species have been reported to coexist in many areas (FAO, 1996). Vegetation types, climate, altitude and presence of suitable animal host determine the distribution and abundance of tsetse flies (Stephen, 1999). The observed differences in abundance of Glossina tachinoides and G. $p$. palpalis in Pantaki, the study area; could be due to differences in microhabitat and host preference of the two species. Glossina tachinoides although, typically a riverine species, were found in the area due to the presence of savannah woodlands in the area.

The higher number of $G$. p. palpalis to $G$. tachinoides in the area could be due to reduced vegetation and dried streams which destroy the habitat of $G$. tachinoides resulting in reduced fly abundance according to FAO, 1996, although Davies, 1997 reported that $G$. tachinoides displays strong adaptation to peridomestic habitat. The presence of G. tachinoides and G. palpalis is of significance; these species are important vectors of both human and animal trypanosomiasis (Fajinmi et. al., 2007; Hendrickex et. al., 2000). Although, both species are less suited to dry conditions, they tend to survive in vegetations with enough shelter from wind (Mellanby, 1936; Okoh et. al., 2012).

The relative abundance of $139(66.8 \%)$ G. p. palpalis and 69 (33.2\%) G. tachinoides agree with the findings of Kalu, 1991 while for Okoh et al, 2012; it shows that $G$. tachinoides are more abundant than $G$. palpalis. According to the study, Glossina 
palpalis and Glossina tachinoides recorded relative abundance of $76 \%$ and $84 \%$ for wet season and, $24 \%$ and $16 \%$ for dry season respectively.

A lot has been done to the control of trypanosomiasis but only $10 \%$ of the infected areas final onslaught on the vector is being planned under the aegis of the Pan African Tsetse and Trypanosomiasis Eradication Campaign (PATTEC) (Ahmed, 2007), this could be as a result of active surveillance that makes the exact present situation of the disease in many parts of Africa and has led to a breakdown of control strategies.

\section{REFERENCES}

Ahmed, A. B. (2007). High Trypanosoma Infections in Glossina palpalis palpalis Robineau Desvoidy 1830 in Southern Kaduna State, Nigeria. Science World Journal, 2:1-7.

Challier, Larveissiere (1973). UN nouveau piege pour la capture des Glos (Glossina: Diptera, Muscidae) description et essays sur le terrain. Cah. ORSTOM. Series Entomologie Medicale et Parasitologie 11:251-262.

Davies (1977). Tsetse flies in Nigeria. Oxford University Press, Ibadan, p. 34.

Desta, M., Menkir, S. and A. Kebede (2013). The study on tsetse fly (Glossina species) and their role in the trypanosome infection rate in Birbir valley, Baro Akobo River system. Western Ethiopia. J. Vet. Med. Anim. Health., 5(7):186-94.

Fajinmi. A.O.,Yahaya, J.A. and O.O. Faleke (2007). Trypanosome and filariae species in slaughtered cattle in Kaduna abbatoir, Nigeria. Anim. Prod. Res. Advan., 3(3) 209211. Journal, 2:1-7.

FAO (1996). Tsetse Biology and Ecology. Their role in the epidemiology and control of Trypanosomiasis. CABI Publication, pp. 17429-17647.

Fernandez, D., Gonzalez-Baradat, B., Eleizalde, M., Gozalez-Marcano, E., Perrone, T. and M. Mendoza (2009).
Trypanosoma evansi: A comparison of PCR and parasitological diagnostic tests in experimentally infected mice. Experimental Parasitology, 121:1-7.

Gutierrez, C., Corbera, J. A., Morales, M. and P. Buscher (2006). Trypanosomosis in goats (Current status). Annals of the New York Academy of Sciences, 1081:300-310. Https://en.climate-data.org/africa/ nigeria/kaduna/kaduna-539/)

Isaac, C., Ciosi, M., Hamilton, A., Scullion, K. M., Dede, P., Igbinosa, I.B., Oyebiguwa, P., Nmorsi, G., Masiga, D., Michael, C. and R. Turner (2016). Molecular Identification of different Trypanosome species and subspecies in Tsetse Flies of Northern Nigeria. Parasites and Vectors, 9:301 DOI 10.1186/s13071016-1585-3.

Jawonisi, I.E. (1988). Tsetse control/eradica-tion in Nigeria: history achievements and future plans. Invited paper, FAO/IAEA Regional Training Course on Integrated Control of Tsetse flies with emphasis on SIT Vom, Nigeria, 23rd May-17th June, 1988.

Kalu, A.U. (1991). An outbreak of trypanosomiasis on the Jos Plateau, Nigeria. Trop. Anim. Health Prod., 23:215-216.

Maikaje, D.B., Sanusi, A., Kwewalabye, E.K. and D.I. Saror (1991). The course of expiramental Trypanosoma vivax infection in Uda sheep. VeterinaryParasitology, 38: 267-274.

Mellanby, K. (1936). 'Experimental work with the tsetse fly $G$. palpalis in Uganda,' Parasitology, 31, 193. In: The African Trypanosomiasis. (Mulligan, H.W.; Potts, W.H, Ed) ODA, George Allen \& Unwin. London, 950p.

Molaleane, B., Yeshitla, A., Tilahun, Z. and D. Hailu (2011). Trypanosome Infection Rate in Glossina Pallidipes and Glossina fuscipes fuscipes in Gojeb valley Southwest Ethiopa. Global Veterinary, 6(2): 131-135.

Muturi, C.N., Ouma, J.O., Malele, I.I., Ngure, R.M., Rutto, J.J., Mithofer, K.M., Enyaru, J. and D.K. Masiga (2011). Tracking the feeding patterns of tsetse flies (Glossina Genus) by analysis of bloodmeals 
using mitochondrial cytoch-romes genes. PLoS ONE, 6(2): el17284, DO110.1371/journal 0017284.

National Population Commission (2006). https://en.wikipedia.org/wiki/Kagarko.

Okoh, K.E., Anavhe, A., Ayakat, H.N., Onotu, C.S. Anchau, R. and J.J. Ajakaiye. (2012). Trypanosomes infection in fieldcaptured tsetse flies of the subgenus: Nemorhina in Southern Guinea Savannah Zone of Nigeria. Current Research Journal of Biological Sciences, 4(6): 713-716.

Onyiah, J.A., Na'isa, B.K., Riordan, K. and W. Gregory (1983). Tsetse distribution in Nigeria. Bulletin Animal Health \& Production in Africa, 31(2):141-150.

P.M. Dede, I. Halid, G.A. Omoogun, N.R. Uzoigwe, C.I. Njoku, A.D. Daniel, A.J. Dadah (2005). Current Tsetse and Trypanosomosis Situation on Jos Plateau, Nigeria. Epizootiological Factors that May Enhance Disease Transmission and Spread. Revue Élev. Méd. vét. Pays trop., 2005, 58 (1-2): 31-35.

Samdi, S.M., Abenga, J.N., Fajinmi, A.O., Kalgo, A., Idowu, T. and F. Lawani (2008). Seasonal Variation in trypanosomosis rates in small ruminants at the Kaduna Abattoir, Nigeria. African Journal of Biomedical Research, 11:229-232.
Samdi, S.M., Fajinmi, A.O., Kalejaye, J.O., Wayo, B., Haruna, M.K., Yarnap, J.E., Usman, A.O., Hamra, S.M., Jijitar, A., Ogunwale, R., Bizi, R., Ovhagbedia, R.P. and J.N. Abenga (2010). Periodic Variation in Trypanosoma Infection Rates in Trade Small Ruminats at Slaughter in Kaduna Central Abattoir. Research Journal of Veterinary Sciences, 3:189-193.

Samdi, S.M., Fajinmi, A.O., Kalejaye, J.O., Wayo, B., Haruna M.K., Yarnap, J.E., Mshelai, W.P., Usman, A.O., Hamra, S.M., Jijitar, A., Ogunwale, R., Ovbagbedia, R.P. and R. Bizi (2011). Prevalence of Trypanosome in cattle at slaughter in Kaduna Central Abattoir. Asian Journal of Animal Sciences, 5(2): 162-165.

Solano, Bauyer, Ifard and Cuisance (2010). Cyclical vectors of Trypanosomosis In: Lerfevre, P.C, Chermelte, J., Blancou, R., Uilenberg, G. (Eds), Infections and parasitic Diseases of Livestock, CABI.

Stephen, L.E. (1986). An Trypanosomiasis. A veterinary perspective. Pergamon Press, p. 45

Taylor, T.K., Boyle, D.B. and J. Bingham (2008). Development of TaqMan PCR assay for the detection of Trypanosoma evansi, the agent of surra. Veterinary Parasitology, 135:255-364.

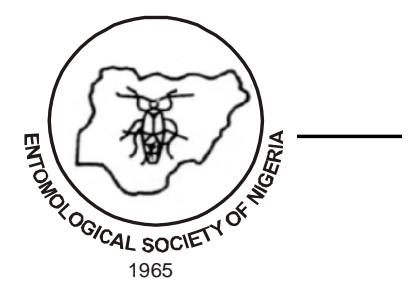

